\title{
Are plant growth retardants a strategy to decrease lodging and increase yield of sunflower?
}

\author{
Marcia Eugenia Amaral Carvalho*, Paulo Roberto de Camargo e Castro, \\ Marcos Vinicius de Castro Ferraz Junior, Ana Carolina Cabrera Machado Mendes
}

University of São Paulo, Piracicaba, SP, Brazil

*Corresponding author, e-mail: marcia198807@hotmail.com

\begin{abstract}
One of the major disadvantages of sunflower cultivation is the increased plant height, making it prone to the lodging. The use of plant growth retardants can be an alternative strategy to reduce plant height; however, these compounds may affect productivity. The aim of this study was to evaluate the effects of plant growth retardants on sunflower development and yield. Four treatments were studied: 1- control; 2- gibberellic acid (GA) $10 \mathrm{mg} \mathrm{L} \square$; 3- trinexapac-ethyl (TE) $5 \mathrm{~mL}$ L $\square$, and 4- maleic hidrazide $(M H) 8 \mathrm{~mL} \mathrm{~L}$. TE and $M H$ decreased plant height (16.9 and 35.9\%, respectively); however, only TE positively influenced capitulim diameter and dry mass $(46.7$ and $311 \%$, when compared to control) at 60 days after planting (DAP). At 81 DAP, dry mass of capitulum did not differ among control and TE-treated plants. On the other hand, $\mathrm{MH}$ impaired diameter and dry mass of capitulum (92.9 and $74.7 \%$, respectively). It can be concluded that the application of TE is a potential strategy to decrease lodging probability without affecting sunflower yield. Furthermore, although $\mathrm{MH}$ negatively affected sunflower development, its use on the crop cannot be excluded since other doses, frequencies and moment of application can be studied.
\end{abstract}

Key words: Helianthus annuus, maleic hidrazide, trinexapac-ethyl

\section{Os retardadores de crescimento vegetal são uma estratégia para diminuir o acamamento e aumentar a produção de girassol?}

\section{Resumo}

Uma das principais desvantagens do cultivo do girassol é a elevada altura da planta, tornando-a propensa ao acamamento. Porém, o uso de retardadores de crescimento vegetal pode ser uma estratégia alternativa para diminuir o porte da planta; no entanto, estes compostos podem afetar a produtividade. $\mathrm{O}$ objetivo deste estudo foi avaliar os efeitos de retardadores de crescimento no desenvolvimento e na produção de girassol. Foram testados quatro tratamentos: 1- controle; 2- ácido giberélico (GA) 10 mg L ${ }^{\square}$; 3- etil-trinexapac (ET) $5 \mathrm{~mL} \mathrm{~L}$ e 4- hidrazida maleica (HM) $8 \mathrm{~mL}$ $\mathrm{L}^{\square}$. ET e HM reduziram a altura das plantas (16,9 e 35,9\%, respectivamente); no entanto, apenas ET influenciou positivamente o diâmetro e massa seca dos capítulos (46,7 e 31 1\%, quando comparado com o controle) aos 60 dias após o plantio (DAP). Aos 81 DAP, a massa seca dos capítulos não diferiu entre plantas controle e tratadas com ET. Por outro lado, HM prejudicou o diâmetro e a massa seca dos capítulos (diminuição de 92,9 e 74,7\%, respectivamente). Conclui-se que a aplicação de ET é uma estratégia em potencial para diminuir a probabilidade de acamamento sem impactar o rendimento do girassol. Além disso, embora $\mathrm{MH}$ tenha afetado negativamente o desenvolvimento do girassol, seu uso na cultura não pode ser excluído, uma vez que outras doses, frequências e momento de aplicação podem ser estudados.

Palavras-chave: etil-trinexapac, Helianthus annuus, hidrazida maleica 
The sunflower (Helianthus annuus) is cultivated in several regions of the world, since this crop is adapted to a wide range of edaphic and climatic conditions, such as different latitude, longitude, and photoperiod (EMBRAPA, 2015). Currently, 35,000,000 Mt of sunflower grains are produced; from them, an oil with excellent nutritional traits is extracted for human consumption, and is also used as a source for biodiesel production (EMBRAPA, 2015). The grains are also used to produce meal for animal feed, and sunflower inflorescence (capitulum) have a great ornamental potential due to its attractive colors (Wanderley et al., 2014; EMBRAPA, 2015).

However, one of the major disadvantages of sunflower cultivation is the increased plant height (Wanderley et al., 2014), making it prone to the lodging in areas with strong winds and storms. The selection of appropriated cultivar is a strategy to decrease wind damage on the crop, since there is considerable variation among genotypes (Wanderley et al., 2014; EMBRAPA, 2015). However, the use of plant growth regulators is a pratical alternative to solve this problem (Wanderley et al., 2014), reducing plant height and facilitating mechanical harvest.

Plant growth regulators are synthetic compounds that normally bind to receptors in plant cells, triggering a range of cellular changes and consequently affecting initiation or modification of tissues and organs (Taiz \& Zeiger, 2010). Among them, there are the plant growth retardants that may decrease stem elongation, increase chlorophyll content, and change root growth (Fletcher et al., 2000; Carvalho et al., $2013,2014)$. Furthermore, plant growth retardants improve plant tolerance to abiotic stresses due to the influence on metabolisms of enzymatic and non-enzymatic compounds (Fletcher et al., 2000; Elansary \& Salem, 2015; Etemadi et al., 2015), and also decreasing the occurrence of a range of diseases (Spinelli et al., 2010; Ok et al., 2011).

Maleic hydrazide (MH) avoids cell division in the apical meristem of plants; on the other hand, trinexapac-ethyl (TE) inhibits the biosynthesis of gibberellins, both reducing unwanted shoot growth (Fletcher et al., 2000). However, the effects of plant growth retardants in plants depends on several factors, and its negative influence on commercialized or edible plant portions were documented (Fletcher et al., 2000; Carvalho et al., 2014; Wanderley et al., 2014). Such facts expose the need of more research to obtaining adequate knowledge for rational use of these compounds in agriculture. Therefore, the objective of this study was to evaluate the effects of $\mathrm{MH}$ and TE on sunflower development and yield.

The experiment was carried out under environmental conditions in Piracicaba, SP, Brazil $\left(22^{\circ} 42^{\prime} \mathrm{S}\right.$ and $\left.47^{\circ} 38^{\prime} \mathrm{W}\right)$, from August to November 2013. Weather data during the experimental period are shown in the Supplementary Table. Sunflower ( $H$. annuus Cv. Comum Rajado) seeds were placed in plastic containers $\left(20 \mathrm{dm}^{3}\right)$ filled with a mixture of clay, manure and sand [2:1:1 $(v: v: v)]$, respectively. The fertilizer (NPK 4:14:8) was applied to the substrate, following the recommendations for this crop. Ten days after planting (DAP), a homogenous adjustment was made to ensure that three seedlings remained in each pot. Furthermore, plants were irrigated as needed to avoid water stress.

There were four treatments: 1) control (water); 2) gibberellic acid $\left.\left(\mathrm{GA}_{3}\right) 10 \mathrm{mg} \mathrm{L}^{-1} ; 3\right)$ trinexapac-ethyl (TE) $5 \mathrm{~mL} \mathrm{~L}^{-1}$, and 4) maleic hidrazide $(\mathrm{MH}) 8 \mathrm{~mL} \mathrm{~L}^{-1}$; which were applied through foliar sprays and until the drip point, at 30 days after planting (DAP). Gibberellin as additional reference to the control plants was used.

Plant height, chlorophyll content, inflorescence diameter, leaf area and shoot dry mass were evaluated at 60 DAP. Plant height was provided by distance from the stem base to inflorescence insertion. Chlorophyll content was measured by chlorophyll meter Minolta SPAD502, in two points of newly expanded leaves and outside the central rib area. Diameter of capitulum was determined with a pachymeter. Height, relative chlorophyll content, and capitulum diameter were obtained from the arithmetic mean of the values observed for three plants per pot.

Leaf area (LA) was determined through Area Meter Li-Cor 2000 equipment. Subsequently, leaves, stems and inflorescences were placed in an oven at $65 \pm 2{ }^{\circ} \mathrm{C}$ for 4 days, to obtain the 
dry mass of leaves (DML), stems (DMS), capitulum $(D M C)$ and shoot $(D M S=D M L+D M S+D M C)$. Leaf weight ratio $(L W R=D M L / D M S)$, leaf area ratio $(L A R=L A / D M S)$ and specific leaf area (SLA = LA) $D M L)$ were also calculated. Leaf area, dry mass of plant organs and the subsequently calculated indexes were obtained from one plant per pot.

At the end of the biological cycle (81 DAP), yield was evaluated as dry mass of capitulum which was obtained by arithmetic mean of the values observed for the two plants that remained in each pot. The experimental design was a completely randomized with four treatments and six repetitions. The obtained data were submitted to analysis of variance $(p \leq$ 0.05) through SAS statistical software (SAS, 2011). Duncan's test ( $\square \leq 0.05$ ) was used to estimate the least significant difference among treatments. Furthermore, Pearson's correlation analysis ( $\mathrm{p} \leq$ 0.05) was performed in order to obtain more information about the evaluated parameters.

Plant growth regulators applied on sunflower plants significantly affected height, specific leaf area, chlorophyll content, diameter and dry mass of capitulum. As observed in Figure 1A, the application of TE and $\mathrm{MH}$ resulted in a decrease of plant height (16.9 and 35.9\%, respectively).

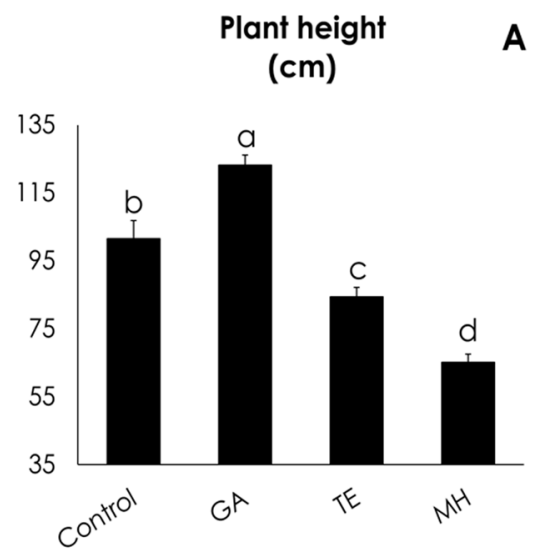

A

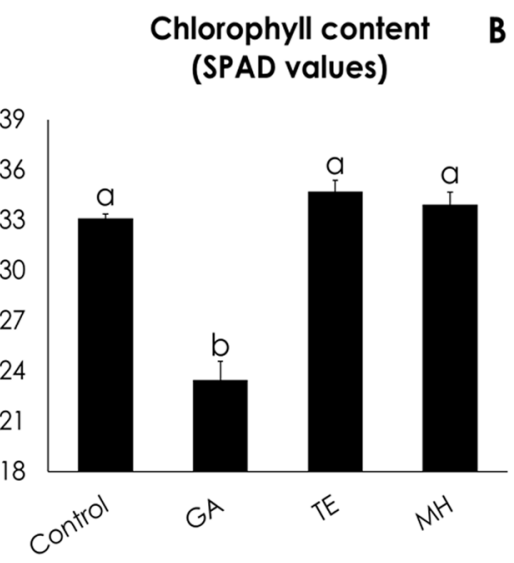

Figure 1. Plant height and leaf chlorophyll content in sunflower (Helianthus annuus cv. Comum Rajado) treated with gibberellic acid $\left(\mathrm{GA}_{3}\right) 10 \mathrm{mg} \mathrm{L}{ }^{\square}$, trinexapac-ethyl (TE) $5 \mathrm{~mL} \mathrm{~L}^{\square}$ and maleic hidrazide $(\mathrm{MH}) 8 \mathrm{~mL} \mathrm{~L}^{\square}$, at 60 days after planting. Means followed by same letters do not differ by Duncan's test ( $\alpha \leq 0.05)$. Bars represent the standard errors.

Both compounds are able to trigger height reduction (Carvalho et al., 2013, 2014), but they act through distinct mechanisms (Fletcher et al., 2000; Jabee et al., 2008). Maleic hydrazide inhibits mitosis and meiosis in meristematic regions (Jabee et al., 2008). On the other hand, trinexapac-ethyl impairs gibberellin metabolism, decreasing the amount of this hormone in plants (Fletcher et al., 2000) and, consequently, reducing plant height since gibberellins are a hormone responsible for cell division and expansion (Taiz \& Zeiger, 2010). It also can be noted that plant height was significantly $(p=$ $0.0008)$ and negatively ( $r=-63.9 \%$ ) correlated to spad values, as exhibited in Table 2.

Table 2. Pearson's correlation analysis among height (HGT), chlorophyl content (SPAD values), specific leaf area (SLA), capitulum diameter (DMT), and capitulum dry mass at 60 (DMC60) and 81 (DMC81) days after planting of sunflower 'Comum Rajado' plants treated with trinexapac-ethyl, maleic hidrazide, gibberellic acid and water (control)

\begin{tabular}{lcccccc}
\hline & HGT & SPAD & SLA & DMT & DMC60 & DMC81 \\
\hline HGT & - & $-63.96^{* * *}$ & $53.25^{* *}$ & $72.73^{* * *}$ & $46.35^{*}$ & $53.01^{* *}$ \\
SPAD & & - & $-41.40^{*}$ & $-31.89^{\text {ns }}$ & $-23.98^{\text {ns }}$ & $-14.55^{\text {ns }}$ \\
SLA & & & - & $48.28^{*}$ & $22.09^{\text {ns }}$ & $33.47^{\text {ns }}$ \\
DMT & & & - & $-75.25^{* * *}$ & $76.67^{* * *}$ \\
DMC60 & & & & - & $44.12^{*}$ \\
DMC81 & & & & & & - \\
\hline
\end{tabular}


Previous studies showed that the use of plant growth retardants is related to changes in chlorophyll content (Fletcher et al., 2000; Carvalho et al., 2013), but there were no differences in spad values among control and plants treated with TE and MH (Figure 1B).

However, application of gibberellin reduced chlorophyll content $129.1 \%$, spad values), probably due to 'dilution effect' of the pigments in leaves since there was an increase $(10.2 \%)$ in specific leaf area (Figure 2A). This hypothesis is grounded by Pearson' correlation analysis, because specific leaf area was inversely correlated to spad values ( $r=-41.4, p<0.05)$.

Nevertheless, this hypothesis did not explain totally this result because ET and $\mathrm{MH}$ reduced specific leaf area (until 12.7\%, respectively), but did not change spad values. Thus, although we did not perform the direct analysis of chlorophyll content, changes in its amount are not excluded since gibberellin and phytol compounds can be originated from the same precursor (Fletcher et al., 2010; Taiz \& Zeiger, 2010).

As showed in Figure 2B, application of GA, TE and $\mathrm{MH}$ changed capitulum diameter, when compared to the control plants. According Pearson's correlation analysis, capitulum diameter was related to dry mass of inflorescences at 60 $\operatorname{DAP}(r=75.5 \%, p=0.0001)$. It can be observed that TE and GA positively influenced the capitulum diameter (46.7 and $43.1 \%$, respectively), although they probably acted by different ways. However, the application of TE was the only treatment that was able to increase capitulum dry mass $1311 \%$, when compared to control) at 60 DAP (Figure 3A).
Specific leaf area $\left(\mathrm{cm}^{2} \mathrm{~g}^{-1}\right)$

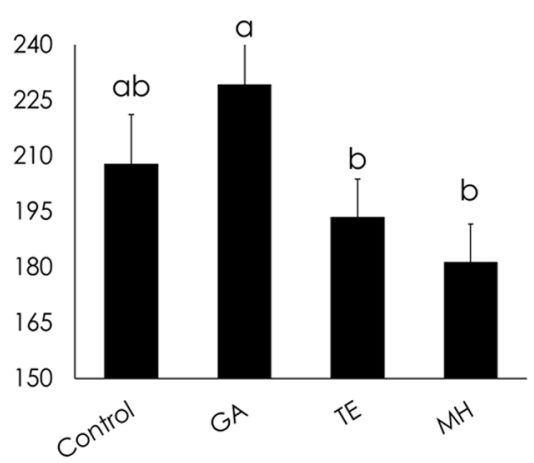

Capitulum diameter (mm)

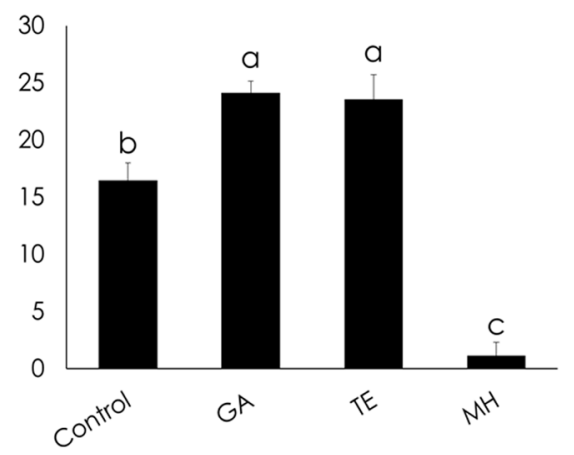

Figure 2. Specific leaf area and capitulum diameter of sunflower (Helianthus annuus cv. Comum Rajado) plants treated with gibberellic acid $\left(\mathrm{GA}_{3}\right) 10 \mathrm{mg} \mathrm{L} \square$, trinexapac-ethyl (TE) $5 \mathrm{~mL} \mathrm{~L}^{\square}$ and maleic hidrazide $(\mathrm{MH}) 8 \mathrm{~mL} \mathrm{~L}^{\square}$, at 60 days after planting. Means followed by same letters do not differ by Duncan's test ( $\square \leq 0.05$ ). Bars represent the standard errors.

Dry mass of capitulum (g) 60 DAP

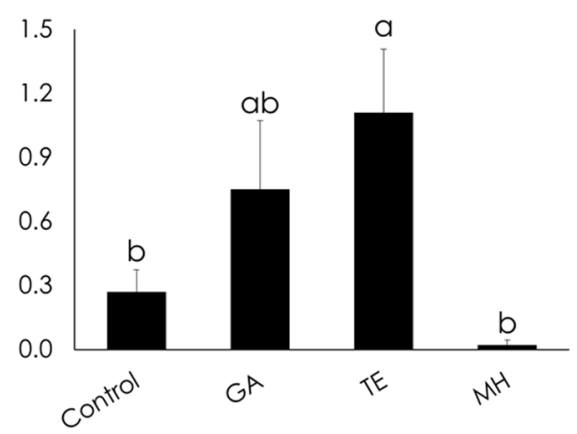

A

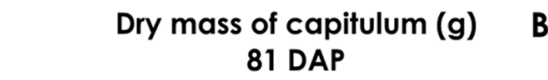

Figure 3. Capitulum dry mass at 60 and 81 days after planting (DAP) of sunflower (Helianthus annuUs $\mathrm{cv}$. Comum Rajado) plants treated with gibberellic acid $\left(\mathrm{GA}_{3}\right) 10 \mathrm{mg} \mathrm{L}^{-1}$, trinexapac-ethyl (TE) $5 \mathrm{~mL} \mathrm{~L}^{-1}$ and maleic hidrazide (MH) $8 \mathrm{~mL} \mathrm{~L}^{-1}$. Means followed by same letters do not differ by Duncan's test ( $\alpha \leq$ 0.05). Bars represent the standard errors. 
Nevertheless, at 81 DAP, dry mass of capitulum did not differ among control, trinexapac-ethyl and gibberellic acid-treated plants (Figure 3B), indicating that the application of TE is a good strategy to decrease plant height with no negative effect on yield. This result leads us to the following hypothesis: TE can induce early floral development, but its action decrease with time; therefore, the capitulum of control and gibberellic acid-treated plants can achieve the same developmental stage. Thus, a new application of TE may be enhance the positive effects of this compound on sunflower crop.

On the other hand, $\mathrm{MH}$ impaired the diameter and dry mass of capitulum (92.9 and $74.7 \%$, respectively), when compared to control. Application of paclobutrazol in doses higher than $2 \mathrm{mg} \mathrm{L}^{-1}$ also impaired capitulum development in 'BRS Oásis' and 'Helio 358' sunflower cultivars, reducing dry mass (88 to 92\%) and diameter (until 68\%) of capitulum (Wanderley et al., 2014). Paclobutrazol is a plant growth retardant that also disturbs gibberellin biosynthesis (Fletcher, 2000; Rademacher et al., 2000), but it acts on a distinct enzyme of the biosynthetic pathway of this hormonal class, when compared to TE (Fletcher, 2000; Rademacher et al., 2000).

Furthermore, according to Wanderley et al. (2014), paclobutrazol had different effects on sunflower cultivars with distinct purposes [i.e. for grain production (Helio 358) and as ornamental plant (BRS Oásis)], since its effects were more pronounced in the first cultivar when comparedto the last one. These authors selected the paclobutrazol dose of $2 \mathrm{~mL}^{-1}$ as the best to be used for production of small plants that yielded capitulum with good ornamental traits. However, when the objective is the grain production, this dose is not recommended because dry mass of capitulum was very affected, showing a reduction of 55 and $71 \%$ in 'BRS Oásis' and 'Helio 358', respectively.

It can be concluded that the application of TE is a potential strategy to decrease sunflower lodging probability, without negatively affecting yield. Furthermore, although $\mathrm{MH}$ has negatively affected sunflower development, its use on crop can not be excluded since other doses, frequencies and moment of application may be tested. In addition, taking into consideration the results found in this study and in those mentioned here, it can be stated that effects of plant growth retardants on sunflower depends on its doses, selected cultivars, and plant developmental stage in the moment of application. Moreover, the best dose of plant growth retardant to be used is a function of the farmer objective (production of grains or ornamental plants).

\section{References}

Carvalho, M.E.A., Castro, P.R.C., Dias, C.T.S. 2013. Plant growth reducers: an alternative to increase the juice production potential and decrease the lodging of sweet sorghum. American-Eurasian Journal of Agricultural and Environmental Science 13: 774-777.

Carvalho, M.E.A., Castro, P.R.C., Dias, K.M.F., Ferraz Junior, M.V.C. 2014. Growth retardants in dry bean plants: impacts on the architecture, photoassimilate partition, and their consequences on the yield. Revista Agrarian 7: 479-484.

Elansary, H.O., Salem, M.Z.M. 2015. Morphological and physiological responses and drought resistance enhancement of ornamental shrubs by trinexapac-ethyl application. Scientia Horticulturae 189: 1-11.

EMBRAPA. Empresa Brasileira de Pesquisa e Agropecuária. 2015. https:// www.embrapa. br/soja/cultivos/girassol <Accessed on: Apr. 09 2015>

Ełemadi, N., Sheikh-Mohammadi, M-H., Nikbakht, A., Sabzalian, M.R., Pessarakli, M. 2015. Influence of trinexapac-ethyl in improving drought resistance of wheatgrass and tall fescue. Acta Physiologiae Plantarum 37: 37-53.

Fletcher, R.A., Gilley, A., Sankhla, N., Davis, T.D. 2000. Triazoles as plant growth regulators and stress protectants. In: Janick, J. (ed.). Horticultural Reviews, John Wiley \& Sons, Oxford, England. p. 55-138.

Jabee, F., Ansari, M.Y.K., Shahab, D. 2008. Studies on the effect of maleic hydrazide on root tip cells and pollen fertility in Trigonella foenumgraecum L. Turkish Journal of Botany 32: 337-344.

Taiz, L., Zeiger, E. 2010. Plant Physiology. Sinaver Associates, Sunderland, England. 782 p.

Wanderley, C.S., Faria, R.T., Rezende, R. 2014. Crescimento de girassol como flor em vaso em função de doses de paclobutrazol. Revista Ceres 61: 35-41.

Spinelli, F., Rademacher, W., Sabatinia, E., Costa, G. 2010. Reduction of scab incidence (Venturia 
Carvalho et al. (2016) / Are plant growth retardants a strategy...

inaequalis) in apple with prohexadione-Ca and trinexapac-ethyl, two growth regulating acylcyclohexanediones. Crop Protection 29: 691698.

Ok, C-H., Popko Jr., J.P., Campbell-Nelson, K. Jung, G. 2011 . In vitro assessment of Sclerotinia homoeocarpa resistance to fungicides and plant growth regulators. Plant disease 95: 51-56. 